\title{
Development and Demonstration of Membrane to Control Potential Pathogen (Legionella sp.) Associated With Cooling Towers
}

\author{
Neha Sharma, Meeta Lavania* and Banwari Lal \\ Microbial Biotechnology, Environmental and Industrial Biotechnology Division, The Energy and Resources Institute (TERI), \\ New Delhi, India
}

OPEN ACCESS

Edited by:

Michael Gormley,

Heriot-Watt University,

United Kingdom

Reviewed by:

Constantinos V. Chrysikopoulos, Technical University of Crete, Greece

Pankaj K. Gupta,

University of Waterloo, Canada

*Correspondence:

Meeta Lavania

meeta/@teri.res.in

Specialty section:

This article was submitted to Water and Wastewater Management,

a section of the journal

Frontiers in Environmental Science

Received: 05 August 2020 Accepted: 24 September 2020

Published: 14 October 2020

Citation:

Sharma N, Lavania M and Lal B (2020) Development and Demonstration of Membrane to Control Potential Pathogen (Legionella sp.) Associated With Cooling Towers.

Front. Environ. Sci. 8:570904. doi: 10.3389/fenvs.2020.570904
The presence of pathogens in industrial cooling towers has been identified as one of the causes of legionellosis, but the tangible hazard has been unrecognized. The major function of a cooling tower in the industries is to transfer heat into the environment through evaporation which leads to an unusual increment in the conductivity of water. Conductivity indicates dissolved solids of water which further facilitate the occurrence of corrosion within the cooling tower systems that may hamper the overall functioning of the cooling tower. The lab-scale study was conducted to developed and demonstrated an efficient membrane to control potential pathogen (Legionella sp.) associated with cooling tower water. In the present study, cooling tower water from various locations was collected and examined for physicochemical parameters $(\mathrm{pH}$, conductivity, salinity, sulfate, and APS reductase) and microbial load. The phylogenetic analysis of the potential sample (with a maximum load of bacterial counts, $\mathrm{P} 1$ ) confirms the presence of Legionella sp., Pseudomonas sp., and Flavobacterium sp. In the present investigation, a unique membrane was developed to regulate the growth of pathogenic contaminants along with sulfate, alkalinity in the cooling tower water. The membrane was capable of reducing conductivity from 6.03 to $4.5 \mathrm{mS} / \mathrm{cm}$ and total microbial load reduced by $40 \%$ by passing through the liquid. The developed membrane was characterized through FTIR that indicated the presence of carbonyl, $\mathrm{C}-\mathrm{CH}_{3}$ and $\mathrm{C}-\mathrm{O}-\mathrm{C}$ group whereas, thermal properties of the membrane was determined through TGA. Thus the developed membrane may be used for environmental monitoring and maintenance, including anti-scale treatment, and physical, chemical, and microbiological control, ensure the good performance of reducing the Legionella sp. risk for public health in cooling tower stations.

Keywords: APS reductase analysis, conductivity (mixed), Legionella sp., FTIR, cooling towers, membranes

\section{INTRODUCTION}

The cooling tower is commonly used in various industries, majorly in power plants in order to maintain cool environment during the thermoelectric power generation (Kenny et al., 2009). The assembly of cooling tower was depicted in Figure 1. In the cooling tower systems, the water keeps on circulating which led to the deposition of dissolved and suspended solids 
(calcium, magnesium, chloride, and silica) in the recirculating water, it may further cause scaling, corrosion within the cooling tower system (Bott, 2009; Altman et al., 2012). The major source of makeup water in cooling tower is either lakes or rivers. The composition of makeup water influences various factors such as biofouling, organic, inorganic and microbial load.

Researchers investigated that the quantity of total dissolved solids was directly correlated with the functioning of cooling tower (Yurudu, 2013). Scaling is one of the major problems that frequently occurred in cooling tower system due to the deposition of insoluble solids that forms hard scale on the surface of cooling tower pipes. The cooling tower water is an excellent source for the growth of microorganisms due to the presence of optimum temperature, micro and macro-nutrients and high surface ratio. Cooling tower is an important source for Legionella growth; they have a large volume of water open to the atmosphere and contain some elements. The genus Legionella is Gram negative bacteria which include approximately 61 species with at least 79 serogroups. The most dangerous species, in $90 \%$ of cases that causes legionellosis, is the Legionella pneumophila sero group 1 (Paranjape et al., 2019).

Various reports showed the abundant presence of pathogenic micro-organism such as L. pneumophila and Pseudomonas aeruginosa in the cooling towers (Wery et al., 2008; Iervolino et al., 2017; Paranjape et al., 2019).

These pathogenic bacteria directly affect the respiratory system of human being. Many researchers has reported the strategies to eliminate the pathogenic contaminants using zinc based biocides that further facilitate the growth of microorganism due to the vigorous availability of nutrients (Duda, 2010). To overcome such problems of pathogenic species, various approaches have been employed involving ultra and microfiltration (Shannon et al., 2008).

In present investigation, an efficient membrane capable of filtering the pathogenic micro-organisms was developed. These methods physicochemical analysis of water was performed in order to determine the chemical content (chloride, sulfate and total dissolved solids) available in cooling tower water. Further, it was analyzed for the presence of general aerobic bacteria, sulfate reducing bacteria (SRB) and pathogenic species such as Legionella. The Legionella presence was further confirmed through biochemical test (oxidase and gelatin hydrolysis essay). The sample was genetically characterized through $16 \mathrm{~S}$ rRNA sequencing. To regulate the contaminants in cooling tower system, in house membrane was developed and characterized through FTIR and TGA. The efficiency of the developed membrane was investigated in 10 liter laboratory scale that confirms the reduction in various contaminants in cooling tower water.

\section{MATERIALS AND METHODS}

\section{Sample Collection}

The water samples of cooling tower was provided by NTPC Limited from five different power stations P1 water sample was collected from Faridabad location with latitude of $28.4089^{\circ} \mathrm{N}$ and $77.3178^{\circ} \mathrm{E}, \quad \mathrm{P} 2$ sample from Unchahar with latitude of $25.9041^{\circ} \mathrm{N}$ and $81.3014^{\circ} \mathrm{E}$, P3 sample was collected from Dadri with latitude of $28.5462^{\circ} \mathrm{N}$ and $77.5561^{\circ} \mathrm{E}, \mathrm{P} 4$ sample was acquired from Jhajjar with latitude of $28.6055^{\circ} \mathrm{N}$ and $76.6538^{\circ} \mathrm{E}$ and P5 sample was collected from different area of Faridabad with latitude of $28.3486^{\circ} \mathrm{N}$ and $77.3623^{\circ} \mathrm{E}$.

The samples were collected in sterile containers and transported to the laboratory (TERI) situated in New Delhi for investigation. Further, samples were stored at $4^{\circ} \mathrm{C}$ for future analysis. Ten liters of cooling water were collected in sterile polytetrafluoroethylene (PTFE) bottles containing a sodium thiosulfate solution $(10 \%, \mathrm{v} / \mathrm{v})$ in order to neutralize any residual disinfectant. All water samples were analyzed for Legionella spp., $P$. aeruginosa, and heterotrophic aerobic bacterial counts.

\section{Physicochemical Parameters of Water}

Water samples were determined for hydrogen ion concentration and conductivity using $\mathrm{pH}$ meter, conductivity meter at, respectively. $\mathrm{pH}$ meter was calibrated with different $\mathrm{pH}$ buffers (4.0, 7.0 and 9.0) whereas conductivity meter was calibrated with standard $\mathrm{KCl}$ solution.

The chemical oxygen demand of water samples were estimated through standard protocols of American Society for Testing and Materials (American Society for Testing and Materials [ASTM], 1995). $0.25 \mathrm{~g}$ of $\mathrm{MgSO}_{4}$ was added in COD tubes with the help of spatula. Around $10 \mathrm{ml}$ of water samples, $5 \mathrm{ml}$ of $0.25 \mathrm{~N} \mathrm{~K}_{2} \mathrm{Cr}_{2} \mathrm{O}_{7}$ and $15 \mathrm{ml}$ of COD acid was added into the tubes. The solution was digested for $2 \mathrm{~h}$ at $150^{\circ} \mathrm{C}$. Further, the digested samples were titrated against $0.1 \mathrm{~N} \mathrm{FeH}_{8} \mathrm{~N}_{2} \mathrm{O}_{8} \mathrm{~S}_{2}$ until wine red color appeared.

The concentration of sulfate was determined through turbidity method. The samples were mixed with $\mathrm{ZnC}_{4} \mathrm{H}_{6} \mathrm{O}_{4}$, buffers and $\mathrm{BaCl}_{2}$ (Morais et al., 2001). The absorbance of turbid solution was observed at $420 \mathrm{~nm}$. The calibration was performed with sodium sulfate standards $(10,20,30,40 \mathrm{mg} / \mathrm{l})$ and $R^{2}$ value was around 0.99 . The chloride content of samples was estimated through $\mathrm{AgNO}_{3}$ titration where $\mathrm{K}_{2} \mathrm{CrO}_{4}$ was used as an indicator (Shukla and Arya, 2018).

\section{Microbial Analysis of Water}

The QuickChek SRB kit employed immunoassay technology to detect SRB in samples. The antibodies found in kit were against adenosine $5^{\prime}$-phosphosulfate reductase (APS) enzyme which was prominently present in all strains of SRB that convert sulfate into sulfide as shown in Figure 2. The antibody and enzyme layer become blue in the presence of chromagen. The general aerobic heterotrophic broth (GHB) comprise of $0.5 \mathrm{~g} / \mathrm{l}$ of yeast extract, $0.5 \mathrm{~g} / \mathrm{l}$ of proteose peptone, $0.5 \mathrm{~g} / \mathrm{l}$ of cas-amino acids, $0.5 \mathrm{~g} / \mathrm{l}$ of glucose, $0.5 \mathrm{~g} / \mathrm{l}$ of starch. $0.3 \mathrm{~g} / \mathrm{l}$ of $\mathrm{C}_{3} \mathrm{H}_{3} \mathrm{NaO}_{3}, 0.3 \mathrm{~g} / \mathrm{l}$ of $\mathrm{K}_{2} \mathrm{HPO}_{4}$, and $0.05 \mathrm{~g} / \mathrm{l}$ of $\mathrm{MgSO}_{4} .7 \mathrm{H}_{2} \mathrm{O}$ was prepared according to NACE guidelines and sterilized for $15 \mathrm{~min}$ at $121^{\circ} \mathrm{C}$. The water samples were incubated at a rate of $1 \%$ into broth and inoculated at $37^{\circ} \mathrm{C}$ for $24 \mathrm{~h}$. Based on the total microbial load, sample (P1) was selected for detailed genetic characterization and identification for the presence of pathogenic species. 


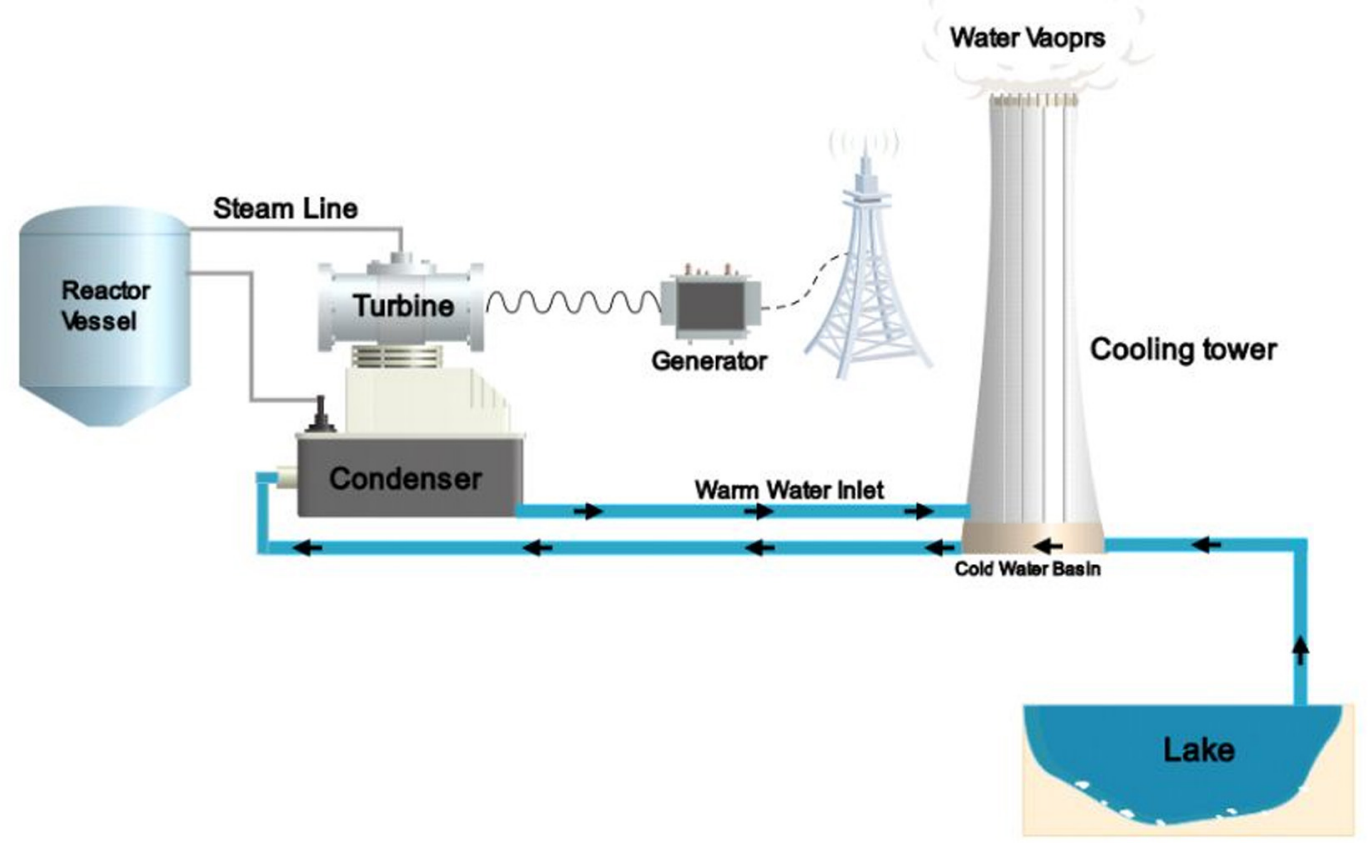

FIGURE 1 | Schematic diagram of cooling tower system and its components.

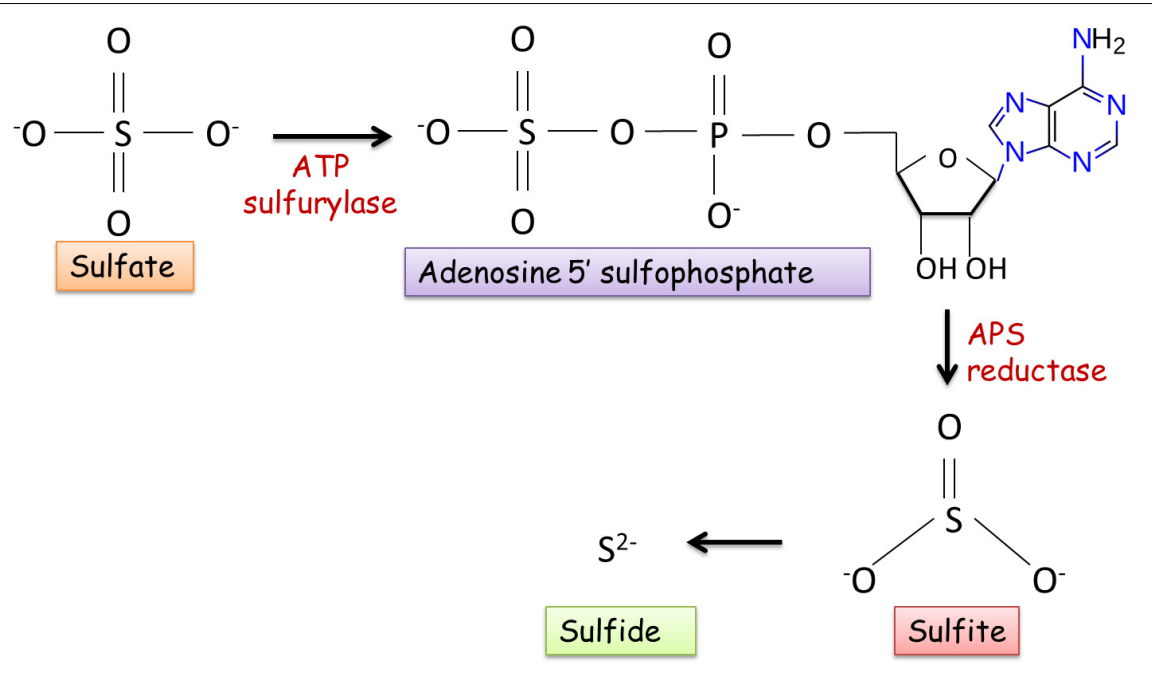

FIGURE 2 | Depicting the conversion of sulfate to sulfide through APS reductase.

\section{Preliminary Screening of Legionella in P1 Water Sample}

To facilitate the growth of Legionella, water sample was diluted in $\mathrm{KCl}-\mathrm{HCl}$ solution (1:10) with $\mathrm{pH}$ of 2.2. The diluted water sample was plated on buffered charcoal yeast agar supplemented with L-cysteine. The plates were incubated at $37 \pm 1^{\circ} \mathrm{C}$ for $24 \mathrm{~h}$ (Parr et al., 2015).

The colonies were morphologically characterized through gram staining. The bacteria were biochemically tested for the presence of cytochrome c enzyme. The colonies were swirled on the glass slide with $1 \%$ of $N, N, N, N$-tetramethyl-pphenylenediamine dihydrochloride reagent whereas, in gelatin hydrolysis test, gelatin agar slants comprises of $12 \%$ gelatin, $0.5 \%$ of peptone and $0.3 \%$ of beef extract was prepared and inoculated with P1 sample (Ditommaso et al., 2015).

\section{Antibiotic Profile Studies of Legionella}

Antibiotic sensitivity test was performed through disc diffusion method using Muller Hinton agar (2 $\mathrm{g}$ of beef extract, $17.5 \mathrm{~g}$ of acid hydrolyzate of casein, $1.5 \mathrm{~g}$ of starch and $17 \mathrm{~g}$ of 


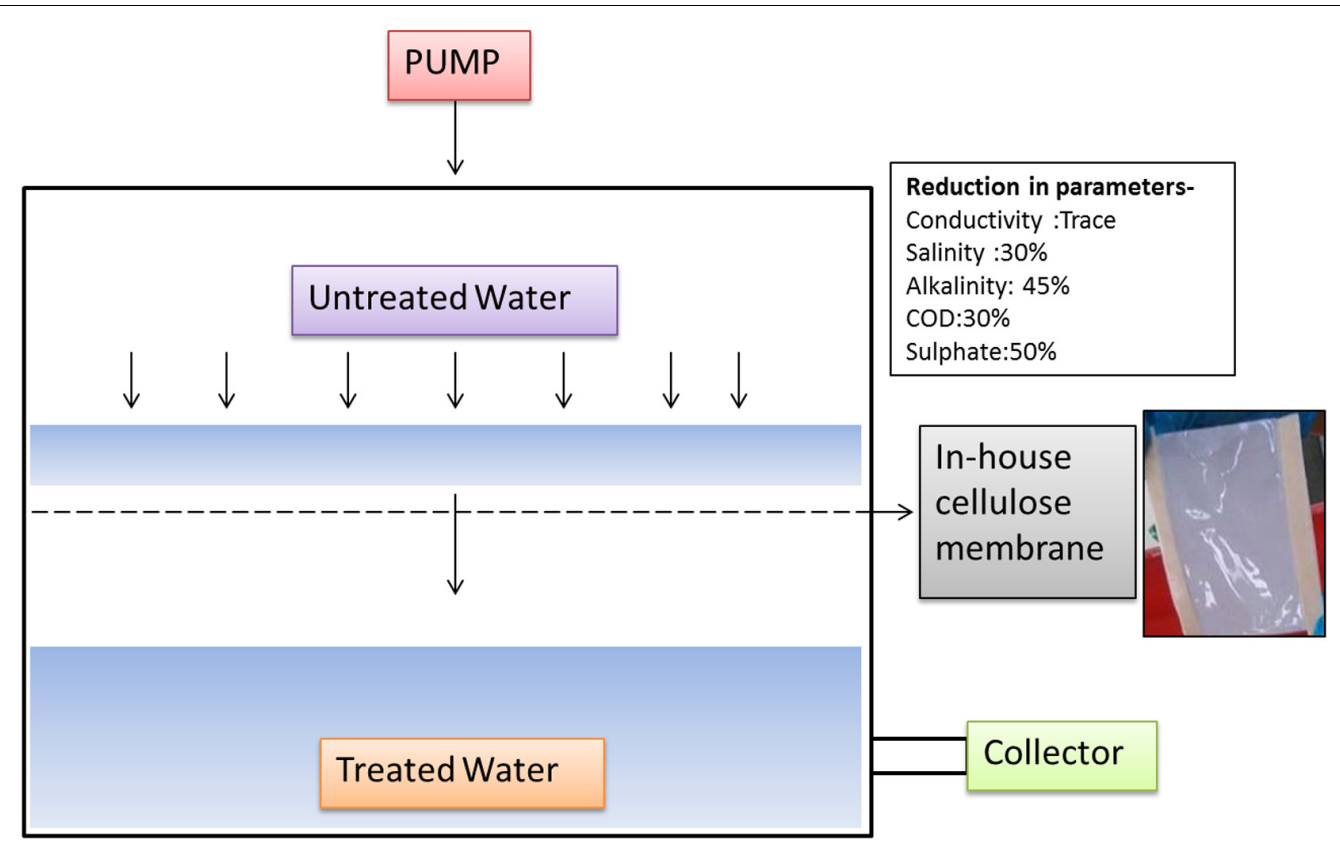

FIGURE 3 | Schematic of laboratory filtration experiment.

TABLE 1 | Physico-chemical analysis of cooling tower water samples.

\begin{tabular}{|c|c|c|c|c|c|c|c|c|}
\hline S.No & $\begin{array}{l}\text { Sample } \\
\text { details }\end{array}$ & $\mathrm{pH}$ & $\begin{array}{l}\text { Conductivity } \\
(\mathrm{mS} / \mathrm{cm})\end{array}$ & $\begin{array}{l}\text { Chloride } \\
\text { (mg/l) }\end{array}$ & $\begin{array}{c}\text { Alkalinity } \\
\text { (mg/l CaCO3) }\end{array}$ & Sulfate (mg/l) & COD (mg/l) & $\begin{array}{c}\text { Total } \\
\text { dissolved } \\
\text { solids (ppm) }\end{array}$ \\
\hline 1. & $\mathrm{P} 1$ & $7.00 \pm 0.02$ & $6.03 \pm 0.015$ & $1379.7 \pm 15$ & $85 \pm 0.2$ & $2400 \pm 20$ & $96 \pm 02$ & $4000 \pm 10$ \\
\hline 2. & $\mathrm{P} 2$ & $7.01 \pm 0.01$ & $5.26 \pm 0.2$ & $1175 \pm 10$ & $45 \pm 0.1$ & $1200 \pm 11$ & $80 \pm 01$ & $3300 \pm 09$ \\
\hline 3. & P3 & $7.08 \pm 0.03$ & $0.80 \pm 0.02$ & $37.2 \pm 09$ & $58 \pm 0.02$ & $835 \pm 08$ & 0 & $512 \pm 05$ \\
\hline 4. & P4 & $7.1 \pm 0.023$ & $0.66 \pm 0.02$ & $22.3 \pm 0.5$ & $60 \pm 0.1$ & $325 \pm 05$ & 0 & $422 \pm 05$ \\
\hline 5. & P5 & $7.05 \pm 0.03$ & $0.25 \pm 0.01$ & $150 \pm 0.1$ & $65 \pm 0.3$ & $628 \pm 09$ & 0 & $166 \pm 02$ \\
\hline
\end{tabular}

Data is average of 3 replicates; ( \pm ) standard error was calculated.

agar). The antibiotic used in the study were Cefuroxime (30), Amikacin $(10 \mu \mathrm{g})$, Co-trimoxazole $(25 \mu \mathrm{g})$, Lincomycin $(15 \mu \mathrm{g})$, Cefoperazone $(75 \mu \mathrm{g})$, Chloramphenicol $(25 \mu \mathrm{g})$, Penicillin G (10 units), Nalidixic acid (30 $\mu \mathrm{g})$, and Colistin (10 $\mu \mathrm{g})$. The culture plates were placed with antibiotic disc and incubated at $37^{\circ} \mathrm{C}$ for $24 \mathrm{~h}$ (Jarraud et al., 2012; Kaiser et al., 2017).

TABLE 2 | Microbial analysis of cooling tower water samples.

\begin{tabular}{lccc}
\hline S.No & $\begin{array}{c}\text { Sample } \\
\text { details }\end{array}$ & $\begin{array}{c}\text { APS reductase (SRB } \\
\text { cell/ml) }\end{array}$ & $\begin{array}{c}\text { Heterotrophic } \\
\text { aerobic bacteria } \\
\text { (CFU/ml) }\end{array}$ \\
\hline 1. & P1 & $1 \times 10^{3}$ & $1 \times 10^{7}$ (Positive) \\
2. & P2 & $\mathrm{BDL}$ & $1 \times 10^{5}$ (Positive) \\
3. & P3 & $1 \times 10^{3}$ & $1 \times 10^{8}$ (Positive) \\
4. & P4 & $1 \times 10^{3}$ & No growth \\
5. & P5 & $1 \times 10^{3}$ & No growth \\
\hline
\end{tabular}

$B D L$ stands for below detection limit.

\section{Community Identification in P1 Sample}

The P1 sample was filtered through $0.45 \mu \mathrm{m}$ pore size, genomic DNA was extracted through PowerSoil DNA isolation kit following the manufacturer's protocol. Further, DNA was

TABLE 3 | Antibiotic assay of Legionella species.

\begin{tabular}{lccc}
\hline S.No & Antibiotics & Sensitivity & Zone of inhibition * (in cm) \\
\hline 1. & CU (Cefuroxine) & Susceptible & $1.1 \pm 0.04$ \\
2. & AK (Amikacin) & Susceptible & $1.7 \pm 0.05$ \\
3. & CO (Co-trimoxazole) & Susceptible & $1.7 \pm 0.07$ \\
4. & L (Lincomycin) & Resistant & No zone of inhibition \\
5. & CS (Cefoperazone) & Susceptible & $0.9 \pm 0.03$ \\
6. & C (Chloramphenicol) & Susceptible & $1.9 \pm 0.08$ \\
7. & P (Penicillin) & Resistant & No zone of inhibition \\
8. & NA (Nalidixic acid) & Susceptible & $2.6 \pm 0.09$ \\
9. & CL (Colistin) & Susceptible & $1.0 \pm 0.04$ \\
\hline
\end{tabular}

*Data is average of 3 replicates; ( \pm ) standard error was calculated. 


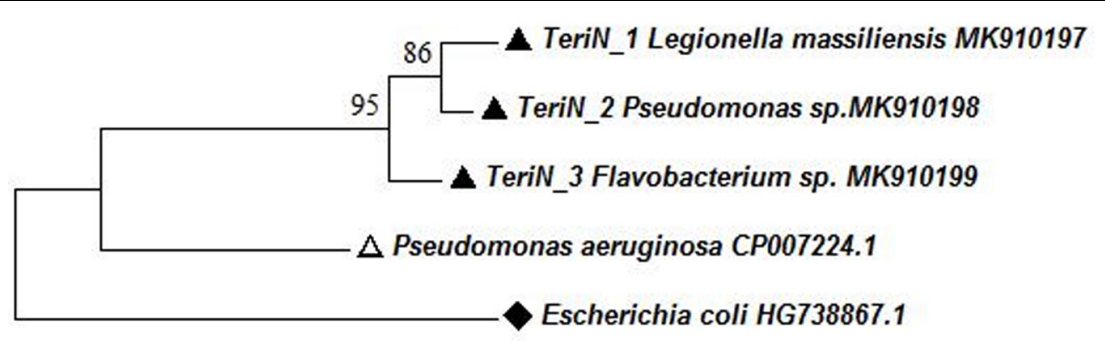

$$
\stackrel{\longmapsto}{0.1}
$$

FIGURE 4 | Phylogenetic tree of bacterial community of P1 sample was constructed using neighbor-joining through bacterial 16S rRNA gene sequences. Numbers at nodes indicated the bootstrap values $>50 \%$ from, 1000 replicates. The scale bar indicates sequence divergence.
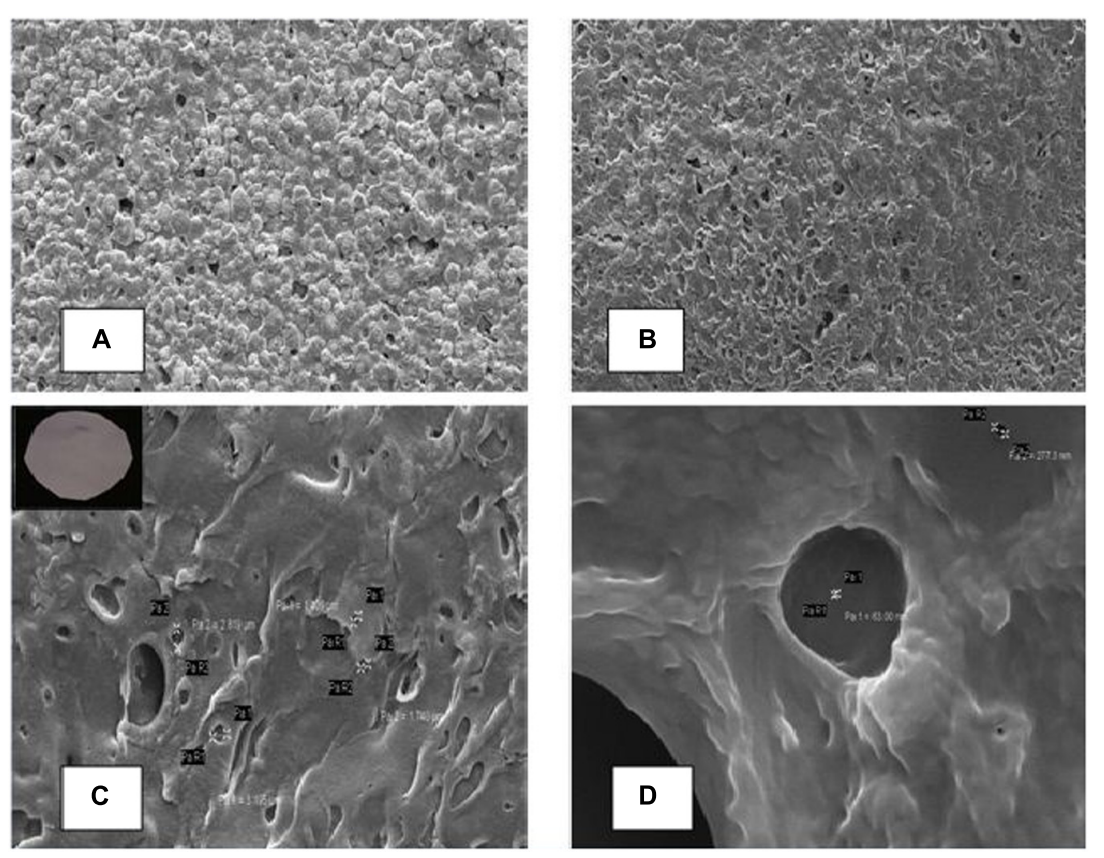

FIGURE 5 | Scanning electron micrographs of cellulose acetate membrane cross sections (A) represents the presence of calcium carbonate in the membrane, (B-D) represents membrane on the left side and its scanning micrograph after the removal of calcium carbonate at different magnifications.

amplified through polymerase chain reaction using universal primer. The cycling program consisted of an initial denaturation step of $95^{\circ} \mathrm{C}$ for $2 \mathrm{~min}$, followed by 25 cycles of $95^{\circ} \mathrm{C}$ for $20 \mathrm{~s}$, $55^{\circ} \mathrm{C}$ for $15 \mathrm{~s}$, and $72^{\circ} \mathrm{C}$ for $5 \mathrm{~min}$, and a final elongation of $10 \mathrm{~min}$ at $72^{\circ} \mathrm{C}$. The amplified product was cloned and transformed as described by Sharma et al., 2018. The transformed colonies were sequenced and sequences were compared with database of Basic Local Alignment Search Tool (BLAST) and deposited in Genbank. Phylogenetic tree was constructed by neighbor-joining method using MEGA version 6.06 programs.

\section{Membrane Experimentation \\ Preparation of In-house Membrane}

A $10 \%(w / v)$ of cellulose acetate (Sigma Aldrich) solution was prepared in acetone. Around $20 \mathrm{~g}$ of $\mathrm{CaCO}_{3}$ and $9 \mathrm{~g}$ of glycerol was added in the suspension. The solution was stir well for $10 \mathrm{~min}$ and was casted on glass plate plastered with scotch tape to provide adequate thickness to the membrane. The membrane was air dried for 5-10 min. To remove $\mathrm{CaCO}_{3}$ particles from the membrane, it was dipped in $0.24 \mathrm{M} \mathrm{HCl}$ solution that showed appearance of gas bubbles (Bott, 2009).

\section{Permeation Measurements}

A permeation test was performed by employing cross flow membrane test unit (comprised of pump, relief valves and pressure guage). The effective membrane area used for permeation measurement was $17.3 \mathrm{~cm}^{2}$. The trans-membrane pressure in fouling test and pure water flux was kept constant at $400 \mathrm{~mm} \mathrm{Hg}$. Membrane flux was determined in terms of volume of permeate per unit time (in hours) and area. The membrane 


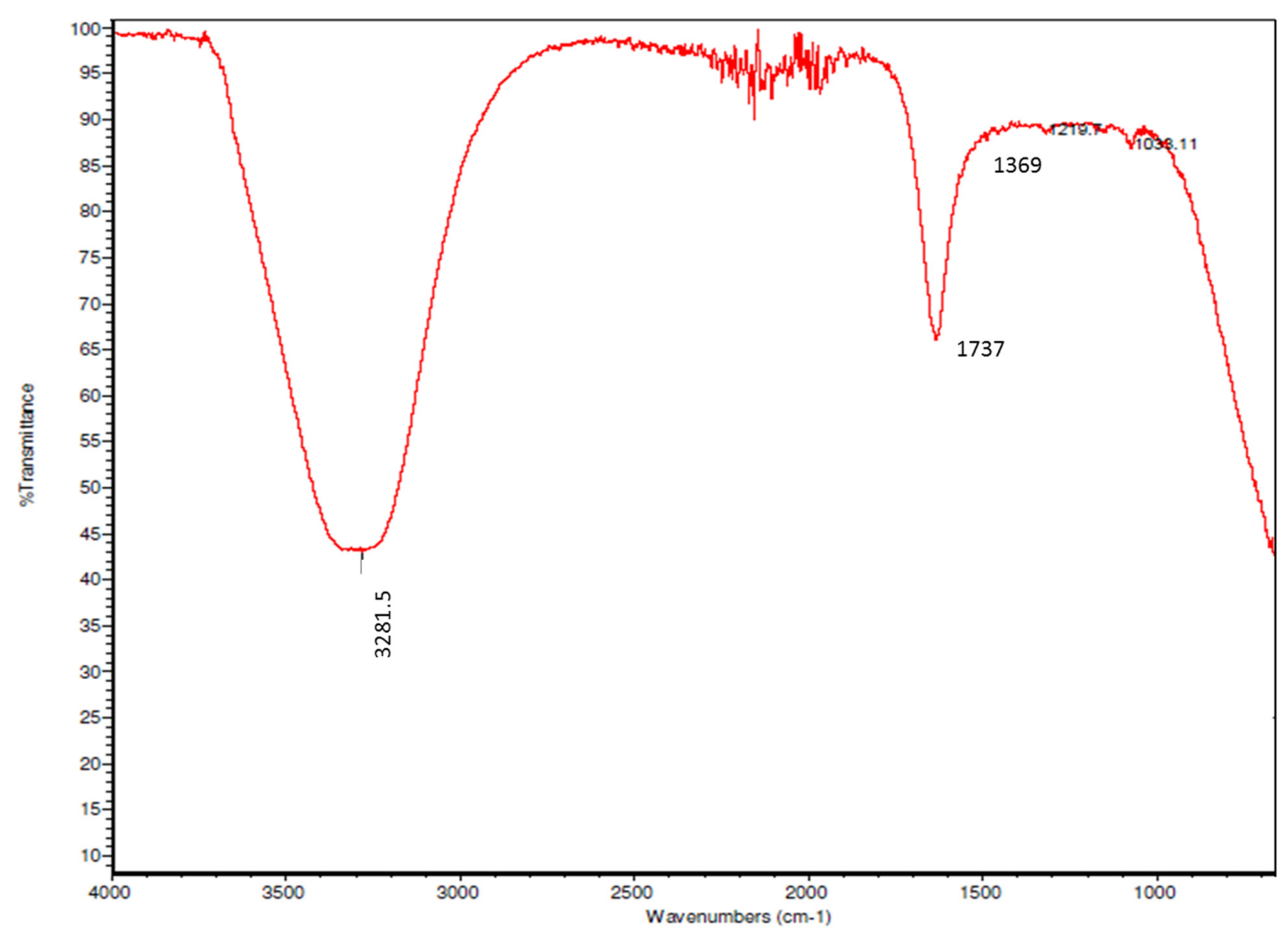

FIGURE 6 | FTIR spectra of in house membrane.

flux was expressed in $\mathrm{lm}^{-2} \mathrm{~h}^{-1}$ (Celik et al., 2011).

$$
\text { Flux }=\text { Volume of permeate } \div \text { Time } \times \text { Area }
$$

Time invested during the filtration process and area of membrane filter was determined using vernier caliper.

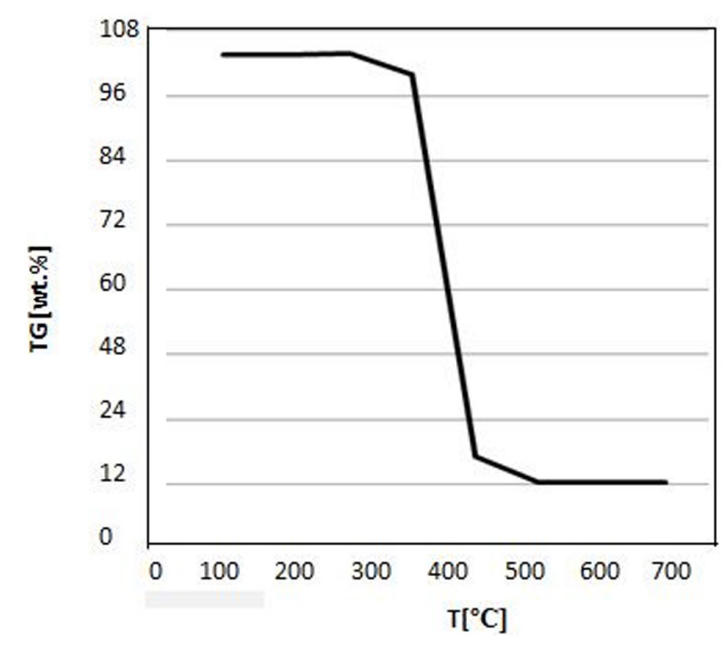

FIGURE 7 | Illustrate TGA thermogram of in house cellulose membrane.

\section{Characterization of In-House Membrane}

The functional groups present in in-house membrane were characterized by Fourier Transform Infrared Spectroscopy (Nicolet, 6700) with a scanning wave number from 4000 to $600 \mathrm{~cm}^{-1}$. The resolution was set at $4 \mathrm{~cm}^{-1}$ with 64 scans per spectrum. An alteration in chemical and physical properties of membrane was analyzed as a function of raise temperature by thermal gravimetric analysis (TGA, Perkin Elmer) under the nitrogen atmosphere with heating rate of temperature $10^{\circ} \mathrm{C} / \mathrm{min}$.

\section{Commercial Membranes}

A commercial membrane (Millipore; Durapore) of pore size $0.22 \mu \mathrm{m}$ was used to compare efficiency of inhouse membrane. The filtration was performed under aseptic conditions.

\section{Water Quality Analysis of filtered water samples}

The filtered water was assessed for hydrogen ions concentration, chemical oxygen demand, salinity, alkalinity and conductivity. The alkalinity of water was determined through sulfuric acid titration. The samples were titrated against $0.02 \mathrm{~N}$ sulfuric acid with phenolphthalein indicator until light pink color appeared. The microbial load (including Legionella sp.) was also estimated using the spread plate technique and colony forming unit (CFU/ml) was determined. 


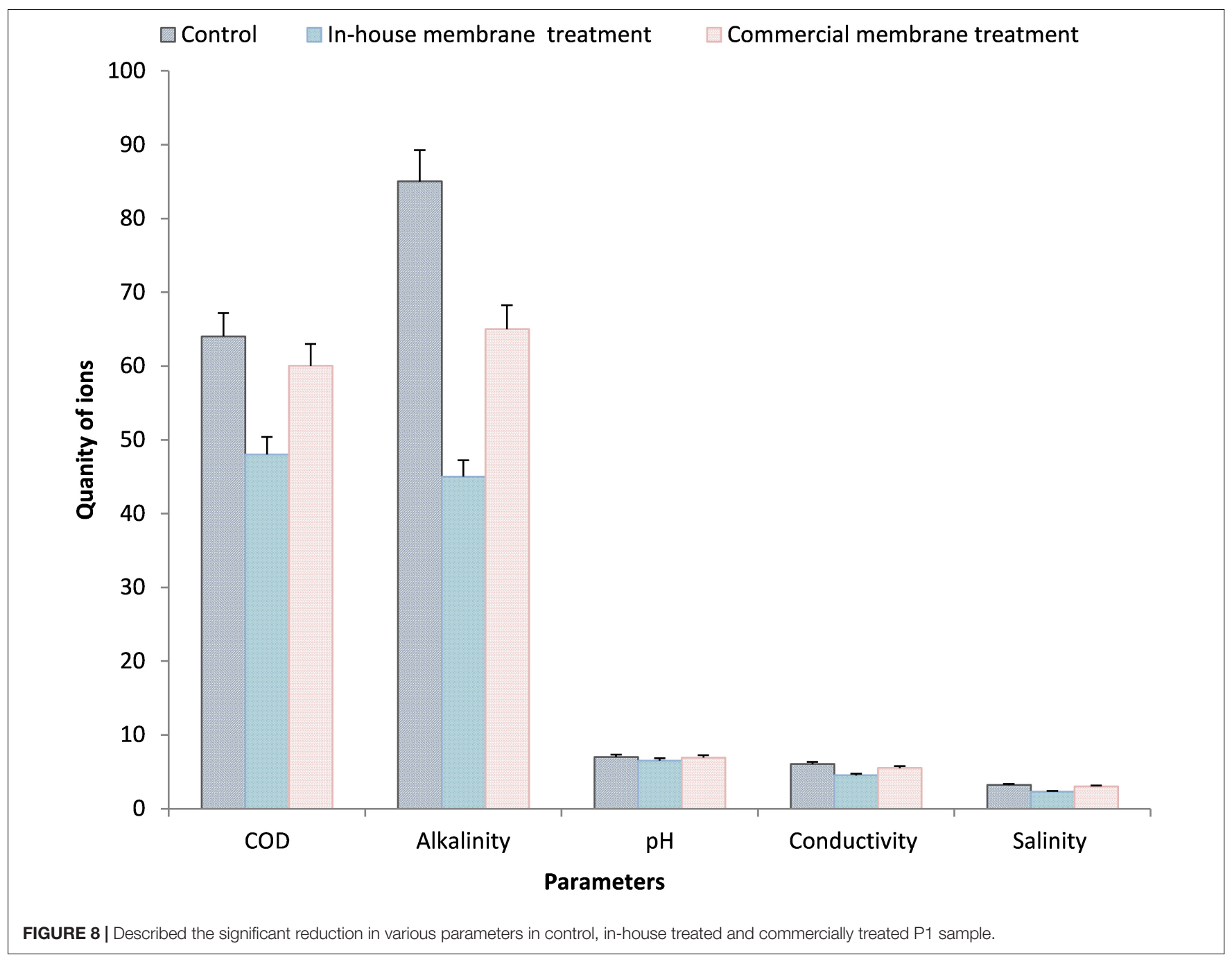

\section{Subsurface Monitoring of Used In-House Membrane}

The surface morphology of used in-house membrane was observed by Scanning electron microscopy (Zeiss EVO MA 10 scanning electron microscope). Micrographs of the membrane were captured digitally using digital image transfer recognition program of Zeiss. The dried sample of the membrane was coated with gold and mounted onto aluminums stabs with adhesive tape and examined at $10 \mathrm{KV}$ (Sharma et al., 2018).

\section{Statistical Analysis}

A statistical analysis was performed using Microsoft Excel 2010. One-way analysis of variance (ANOVA) was performed to identify significant difference between the efficiency of retaining contaminants by commercial and in-house membrane. The probability $(p)<0.05$ represent the significant difference among the variables.

\section{Laboratory Scale Up Study}

Scale up study was performed in a column separated with inhouse membrane as depicted in Figure 3. The column was attached with the vacuum pump. A 10 liter of sample was added into the chamber; filtrate was collected in sterile collector and was analyzed for various microbial and physico-chemical parameters.

\section{RESULTS}

\section{Physicochemical Analysis}

The $\mathrm{pH}$ of water samples (P1, P2, P3, P4, and P5) were near neutral. The neutral $\mathrm{pH}$ of water may facilitate the growth of various micro-organisms. The conductivity of samples was recorded. Among all, P1 showed maximum conductivity of $6.03 \pm 0.015 \mathrm{mS} / \mathrm{cm}$ whereas $5.26 \pm 0.2,0.80 \pm 0.02,0.66 \pm 0.02$, and $0.25 \pm 0.01 \mathrm{mS} / \mathrm{cm}$ was observed in P2, P3, P4, and P5, respectively. Similarly, total dissolved solids were maximum $\left(4.01 \times 10^{3} \mathrm{ppm}\right)$ in P1 sample. The chemical oxygen demand was significantly higher $(96 \pm 02 \mathrm{mg} / \mathrm{l})$ in P1 sample as compared to P2 whereas, other samples does not showed any chemical oxygen demand or it may be below the detection limit. The chloride and alkalinity content of water samples were in the range of $45 \pm 0.1-85 \pm 0.2$ and $22.3 \pm 0.5-1379.7 \pm 15 \mathrm{mg} / \mathrm{l}$, respectively (Table 1). Maximum content of conductivity, total 


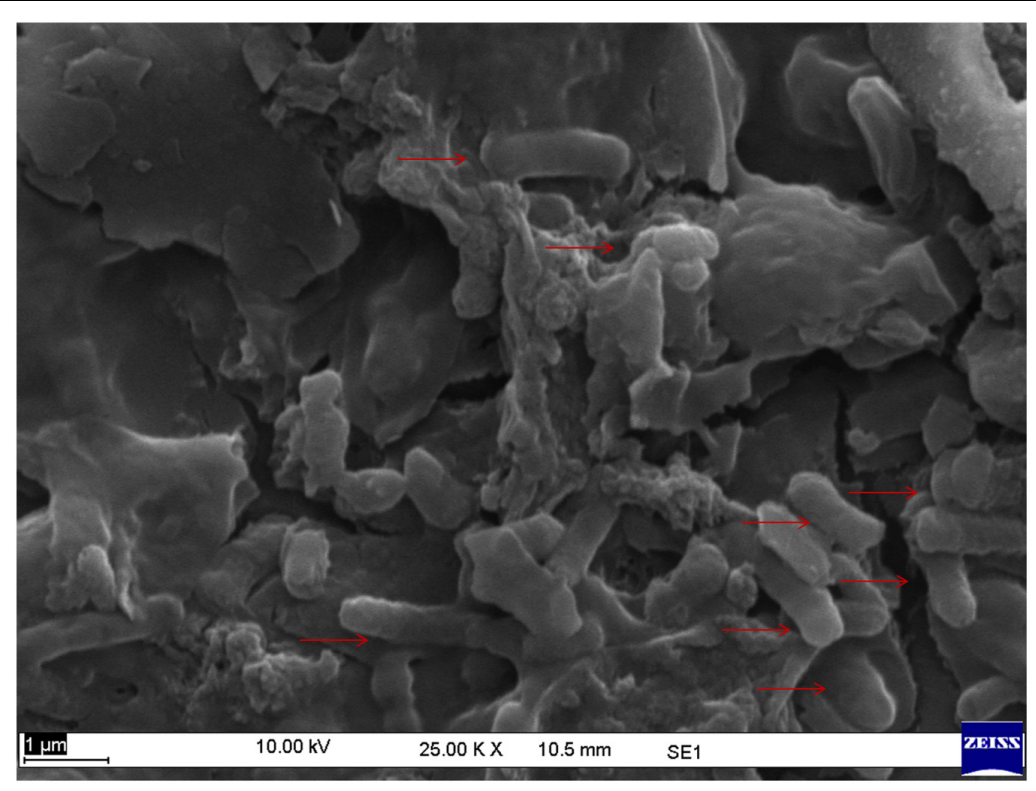

FIGURE 9 | Scanning micrograph of microbial contaminants retained on the surface of in-house membrane.

dissolved solids and chloride may accelerate the metal corrosion in cooling tower system (Samimi, 2013).

\section{Microbial Analysis}

Diverse group of microbes were vigorously found in water sample, including aerobes, anaerobes and SRB. General aerobic bacteria were estimated according to NACE guidelines, the results were described in Table 2. APS reductase data depicted the presence of SRB's in four water samples except P2 where the concentration of SRB's were significantly less (Supplementary Figure S1). The P1 sample was appeared to be highly contaminated with excessive general aerobic bacteria and other contaminants. Further, studies were performed with P1 sample.

\section{Preliminary Study of P1 Sample}

Report of Subbaram et al. (2017) demonstrated that L. pneumophila was the most virulent species as it showed $100 \%$ mortality in suckling mice during pathogenicity studies whereas its presence in the water bodies may pose public health risk. Various studies represented outbreak of Legionellosis in developed countries (Walser et al., 2014). To confirm the presence of Legionella in p1 sample, selective media (buffered charcoal yeast agar) was used. Isolated bacterial colony was appeared to be gram negative, rod shaped as described by Sharma et al., 2019. Colonies were oxidase and gelatinase positive (Supplementary Figure S2).

Further, to determine the pathogenicity of isolated Legionella species antibiotic sensitivity assay was performed where nine different antibiotics were used viz. amikacin, co-trimoxazole, cefuroxime, lincomycin, cefroperazone, chloramphenicol, penicillin G, nalidixic acid, colistin. Legionella species shows resistant against two antibiotics (Lincomycin and Peniciliin G). The Legionella species was susceptible against other antibiotics
(Supplementary Figure S3). The diameter of zone of inhibition was lying in a range of $0.9 \pm 0.03$ to $2.6 \pm 0.09 \mathrm{~cm}$ (Table 3). The results were performed in triplicates and data points were average of the triplicate \pm standard deviation (less than $5 \%$ of average).

\section{Identification and Characterization of P1 Sample}

Uncultured based 16S rRNA sequencing study was characterized in Figure 4. The sequences were available under accession number MK 910197-MK910199. Phylogenetic profile indicates the bacterial genera found in P1 sample was Legionella sp., Pseudomonas sp. and Flavobacterium sp. Legionella species does not shows any antagonistic characteristic in reference with Pseudomonas and Flavobacterium sp. (Bertelli et al., 2018). Previous reports suggested that Pseudomonas, Blastomonas, Methylobacterium, and unclassified genera from Bukholderiaceae family constitute the core micro- biome of cooling tower (Paranjape et al., 2019).

Various studies shows pathogenic bacterial genera intensely detected in cooling tower system have been accompanied with biofilm formation i.e., Legionella, Pseudomonas, Mycobacterium, Leptospira, Achromobacter, and Bosea (Greub and Raoult, 2004; Thomas et al., 2010). Legionella pneumophila has been shown to be one of the utmost abundant members of Legionella community persist in a cooling tower water for a long period of time (Carvalho et al., 2007; Wery et al., 2008; Parthuisot et al., 2010).

\section{Membrane Characterization}

The cellulose acetate membrane was prepared in-house (manually). The presence of calcium carbonate in the membrane slurry makes it fragile. The pores in the membrane were generated after hydrochloric acid treatment, which reacts with 
the calcium carbonate leading to the release of carbon dioxide;

$$
\mathrm{CaCO}_{3}(\mathrm{~s})+2 \mathrm{HCl} \rightarrow \mathrm{CaCl}+\mathrm{H}_{2} \mathrm{O}(\mathrm{aq})+\mathrm{CO}(\mathrm{g})
$$

The glycerol serves as the key ingredients that regulate pore size and gradient along the cross section of the membrane (Hess et al., 2015). The membrane was appeared white in color with robust nature. Figure 5 illustrated the scanning electron micrographs of membrane with the pore size of $0.027-3.0 \mu \mathrm{m}$. Further, permeation study demonstrated gradually reduction in sample when compared with pure water due to the presences of dust, silt and other impurities.

The membrane was characterized by FTIR spectroscopy where spectrum showed distinctive acetate peak at $1737 \mathrm{~cm}^{-1}$ that was associated with the symmetric stretching of carbonyl group $(\mathrm{C}=\mathrm{O})$. The characteristic peaks at $1369,1219 \mathrm{~cm}^{-1}$ wavenumber corresponds to $\mathrm{C}-\mathrm{CH}_{3}$ and $\mathrm{C}-\mathrm{O}-\mathrm{C}$ stretching frequencies, respectively (Gopiraman et al., 2013). The intense peak at 3281.52 corresponds to $\mathrm{O}-\mathrm{H}$ stretching as shown in Figure 6.

The TGA thermogram of the in-house membrane was shown in Figure 7. The volatization of volatile matter was occurred in the initial phase between 25 and $330^{\circ} \mathrm{C}$. The significant thermal degradation of in house membrane was monitored between 330 and $450^{\circ} \mathrm{C}$. The overall weight loss of membrane was around $70-$ 80\% (Arthanareeswaran et al., 2004).

\section{Efficiency of In-House Membrane}

Membrane filtration was employed in cooling tower systems as a treatment option that would allow water re-circulation back to the system. The performance of membranes was tested for sulfate and salinity removal from the water sample of cooling tower (Feng, 2008). Generally, higher the salinity of water, higher will be the energy required for its removal (DiFilippo, 2004; Altman et al., 2012). Membrane systems in general have lower water recovery, but are more economical as compared to other alternative methods.

After the membrane treatment, the filtrate of P1 sample was investigated for various parameters (microbial and physicochemical). The untreated P1 sample serves as a control. The filtrate shows slight reduction in $\mathrm{pH}$ and around $25 \%$ reduction in conductivity, $28 \%$ in salinity, $48 \%$ reduction in sulfate and $47 \%$ in alkalinity. The microbial load of control sample was $1.8 \times 10^{5} \mathrm{CFU} / \mathrm{ml}$ that drastically reduced up to $40 \%$ in treated P1 sample whereas, the CFU/ml of Legionella was also reduced. To compare the efficiency of in-house membrane, the P1 sample was treated with commercial membrane of $0.22 \mu \mathrm{m}$ pore size. The commercial membrane also showed reduction in all the parameters such as $\mathrm{pH}$, salinity, conductivity, alkalinity etc. (Figure 8). The outcomes of commercial membrane illustrated similar pattern as obtained in case of in-house membrane. The inhouse membrane appeared to be cost effective. The cost of overall experiment of membrane generation was relatively low.

Further, study was confirmed through scanning electron microscopy, at magnification of $25,000 \times$. The micrograph of used in-house membrane evidently represents rod shaped contaminants that were retained on the surface of membrane (Figure 9).

\section{Scale Up Susing In-House Membrane}

The treated water was analyzed for various parameters (conductivity, salinity, alkalinity, COD, and $\mathrm{CFU} / \mathrm{ml}$ ). The treated sample showed $30-50 \%$ reduction in COD, alkalinity and salinity. Conductivity was found in traces in treated water sample. The filtration tends to reduce the microbial load, biofilm, and other contaminants in significant amount.

The in-house membrane has capability to reduce particulate matter that can cause clogging and fouling of cooling tower systems. The pore size of filter plays an important role in eliminating the entire particulate matter. Due to this, there will be a reduction in water consumption as water being re-circulated through the system for longer duration. This tends to reduce the energy consumption as filtration reduces the occurrence of scale and fouling on heat exchangers. Due to filtration, biological growth can be controlled and reduction can mitigate potential health problems caused by pathogenic species (Legionella sp.) (Latzer, 2012).

\section{DISCUSSION}

The environmental studies of Legionnaires infection associated with the cooling tower have revealed poorly sustained systems, lack of control procedures, and failure of system equipment. Various investigators and guidelines recommended the regular maintenance of the cooling tower to control the fouling, scaling occurred due to deposition of salts, microbial growth. Additionally, routine examination and implementation of corrective measures have been recommended to reduce the water stagnation. Further measures involve the cleaning of all internal parts, such as the heat exchanger, and removing dirt, dust, dissolved solids, and organic materials.

As described by Krumholz et al., 2013, a great number of the cooling tower did not have a risk assessment and management plan in place, an operational manual available, or standardized cleaning and maintenance procedures, indicating that the Cooling tower operation was not being systematically monitored. The present study was focused on the removal of pathogenic micro-organisms present in the cooling tower water through the developed membrane. Krumholz et al., 2013 described Desulfovibrio species used sulfate as substrate and converted it to adenosyl phosphorsulfate which involved ATP. Further, APS reductase facilitates the reduction of APS to sulfite and AMP. The production of $\mathrm{H}_{2} \mathrm{~S}$ gas tends to accelerate the corrosion in the industrial cooling tower systems (Krumholz et al., 2013).

We hypothesized that the resident microbial population influences the colonization, survival, and proliferation of L. pneumophila in cooling towers. The source of the cooling water P1 was the main factor explaining the difference in the microbial composition of the cooling towers in our study.

The Legionella isolated from the hot water systems were commonly identified as L. pneumophila, in line with the other researchers such as Bargellini et al. (2011). Although 
more than 50 species of genus Legionella was found in the natural environments, most of the species are pneumophila and other lower reservoirs of other species as anysa, longbeachae and micdadei have been described by Edagawa et al., 2008 and Mouchtouri et al., 2007.

A researcher (Han et al., 2012) showed the presence of highly dynamic taxa that suggests the abundance of biofilm forming and biofilm associated microbes in the cooling tower basin (FeiTsao et al., 2019). Another report shows the probability of presence of pathogenic Legionella sp. was around $40 \%$ in Asia, Australia and Europe. Similarly, recent outbreak in New York demonstrated the presence of $38 \%$ of L. pneumophila and $25 \%$ of its isolates (Mouchtouri et al., 2010).

Another report represents that $72 \%$ of samples were contribute L. pneumophila that indicate a possible correlation between diversity of Legionella sp. in water and culturability of L. pneumophila (Llewellyn et al., 2017). Additionally, all the Legionella sp. identified so far in the various investigations are considered to be potentially pathogenic (Burillo et al., 2017). A study emphasized that cooling towers of pharmaceutical plants and oil refinery and found high levels of Proteobacteria, such as Rhodobacteraceae, Sphingomonadaceae, Bradyrhizobiaceae, as well as Cyanobacteria, but no Pseudomonas Bargellini et al. (2011) and Sharmin et al. (2013). Thus, the community composition seems to be influenced by the intrinsic properties of a cooling tower and its geographic location.

The presence of bacterial phyla and Proteobacteria families within cooling towers remains homogenous across all US climate regions. This study represents that climate and geography may have little impact on the microbial communities. A study conducted in Queensland, Australia reported Proteobacteria and Bacteriodetes were the abundant phyla in cooling towers industries (Sharma et al., 2015).

Pseudomonas species, the most prevalent in seawater and industrial water, were reported to cause corrosion on the mild steel, stainless steel and aluminum alloy in industrial habitats (Gubner and Beech, 2000). Pseudomonas has also been shown to cause the corrosion of metal and pitting on the metal surface of cooling tower system. Busalmen et al. (2002) described that corrosion rate tends to accelerate by cathodic reduction caused by catalase enzyme produced by Pseudomonas. In the phylogenetic tree, the isolates exhibited high nucleotide sequence similarity with $P$. aeruginosa and $P$. species with high similarity values of greater than $98 \%$.

The microfiltration and ultrafiltration impartial processes and their combination tends to work efficiently in order to remove the suspended particles, macromolecules and oil as a pretreatment step whereas the combination of ultra-low-pressure nanofiltration and reverse osmosis has been implemented to treat the produced water for greater water quality standards which are potable and for irrigation (Le and Nunes, 2016).

The desalination process occurred in the cooling tower water during the membrane distillation technology is a promising solution. The technology appeared to be much more resistant to the fouling than the pressure driven desalination. The foremost advantage of utilizing membrane distillation despite of nanofiltration was that it involves the saving of energy, make up water and chemicals (Koeman-Stein et al., 2016). Thus, the developed membrane can be used for the industrial application.

\section{CONCLUSION}

Cooling tower are highly efficiency air handling systems, extensively used in the thermal power plants. Our data reveals that the preventive measures, including cleaning, disinfection treatments, physico chemical and microbial analyses was undertaken during the entire operation. Scaling and corrosion of the tower components can affect its functionality and increase the risk of the release of airborne microorganisms, such as Legionella. In the present study the presence of pathogenic bacteria viz. Legionella sp., Pseudomonas sp. and Flavobacterium $\mathrm{sp}$ in the most contaminated water sample (P1) through $16 \mathrm{~S}$ rRNA sequencing. The membrane appeared to be an alternative aspirant which eliminate pathogens in a chemicals free approach and the developed of cellulose membrane was easy and economical which can be implemented in the industrial scale. The results in this study promote a preventive approach for the surveillance of Legionella in cooling tower stations. This may be an important step that will help stakeholders adopt a risk assessment plan, supporting the environmental monitoring studies, and allow for the rapid identification of outbreak sources during epidemiological investigations.

\section{DATA AVAILABILITY STATEMENT}

The original contributions presented in the study are included in the article/Supplementary Material, further inquiries can be directed to the corresponding author.

\section{AUTHOR CONTRIBUTIONS}

NS and ML conceived and designed the experiments. ML and BL provided all the resources for performing experiments. NS performed the experiments and analyzed the data. All authors drafted the work, revised it critically for important intellectual content, and final approval of the version to be published.

\section{ACKNOWLEDGMENTS}

The authors are thankful to the Director General, TERI for providing infrastructural facilities and encouragement to execute the present study. The authors are also grateful to S. K. Dube for providing fruitful guidance.

\section{SUPPLEMENTARY MATERIAL}

The Supplementary Material for this article can be found online at: https://www.frontiersin.org/articles/10.3389/fenvs.2020. 570904/full\#supplementary-material 


\section{REFERENCES}

Altman, S. J., Jensen, R. P., Cappelle, M. A., and Sanchez, A. L. (2012). Membrane treatment of side-stream cooling tower water for reduction of water usage. Desalination 285, 177-183. doi: 10.1016/j.desal.2011.09.052

American Society for Testing and Materials [ASTM] (1995). Standard Methods for Chemical Oxygen Demand (Dichromate Oxygen Demand of Water D1252-95. Philadelphia, PA: ASTM.

Arthanareeswaran, G., Thanikaivelan, P., Srinivasn, K., and Mohan, D. (2004). Synthesis, characterization and thermal studies on cellulose acetate membranes with additive. Eur. Polym. J. 40, 2153-2159. doi: 10.1016/j.eurpolymj.2004. 04.024

Bargellini, A., Marchesi, I., Righi, E., and Ferrari, A. (2011). Parameters predictive of Legionella contamination in hot water systems: association with trace elements and heterotrophic plate counts. Water 45, 2315-2321. doi: 10.1016/j. watres.2011.01.009

Bertelli, C., Courtois, S., Rosikiewicz, M., and Pirion, P. (2018). Reduced chlorine in drinking water distribution systems impacts bacterial biodiversity in biofilms. Front. Microbiol. 9:2520. doi: 10.3389/fmicb.2018.02520

Bott, T. R. (2009). Biofouling control in cooling water. Int. J. Chem. Eng. Res. 9, 1-4. doi: $10.1155 / 2009 / 619873$

Burillo, A., Pedro-Botet, M. L., and Bouza, E. (2017). Microbiology and epidemiology of Legionnaire's disease. Infect. Dis. Clin. N. Am. 31, 7-27.

Busalmen, J. P., Vazquez, M., and De Sanchez, S. R. (2002). New evidences on the catalase mechanism of microbial corrosion. Electrochim. Acta 47, 1857-1865. doi: 10.1016/s0013-4686(01)00899-4

Carvalho, F. R. S., Vazoller, R. F., Foronda, A. S., and Pellizari, V. H. (2007). Phylogenetic study of Legionella species in pristine and polluted aquatic samples from a tropical Atlantic forest ecosystem. Curr. Microbiol. 55, 288-293. doi: $10.1007 / \mathrm{s} 00284-006-0589-1$

Celik, E., Park, H., Choi, H., and Choi, H. (2011). Carbon nanotube blended polyethersulfone membranes for fouling control in water treatment. Water Res. 45, 274-282. doi: 10.1016/j.watres.2010.07.060

DiFilippo, M. N. (2004). Use of Produced Water in Recirculating Cooling Systems at Power Generating Facilities. Palo Alto, CA: National Energy Technology Laboratory.

Ditommaso, S., Ricciardi, E., Giacomuzzi, M., and Arauco, S. R. (2015). Legionella in water samples: how can you interpret the results obtained by quantitative PCR? Mol. Cell Prob. 29, 7-12. doi: 10.1016/j.mcp.2014.09.002

Duda, S. M. (2010). Biological Control in Cooling Water Systems Using Nonchemical Water Treatment Devices, Master's thesis, University of Pittsburgh, Pittsburgh, PA.

Edagawa, A., Kimura, A., Doi, H., and Tanaka, H. (2008). Detection of culturable and nonculturable Legionella species from hot water systems of public buildings in Japan. J. Appl. Microbiol. 105, 2104-2114. doi: 10.1111/j.1365-2672.2008. 03932.x

FeiTsao, H., Scheikl, U., Herbold, C., Indra, A., Walochnik, J., and Horn, M. (2019). The cooling tower water microbiota: Seasonal dynamics and co-occurrence of bacterial and protist phylotypes. Water Res. 159, 464-479. doi: 10.1016/j.watres. 2019.04.028

Feng, Y. (2008). Management of Blowdown from Closed Loop Cooling Systems Using Impaired Waters. Master's thesis, Renmin University of China, Beijing.

Gopiraman, M., Fujimor, K., Zeeshan, K., and Kim, B. S. (2013). Structural and mechanical properties of cellulose acetate/graphene hybrid nanofibers: spectroscopic investigations. Exp. Polym. Lett. 7, 554-563. doi: 10.3144/ expresspolymlett.2013.52

Greub, G., and Raoult, D. (2004). Microorganisms resistant to free-living amoebae. Clin. Microbiol. Rev. 17, 413-433. doi: 10.1128/cmr.17.2.413-433.2004

Gubner, R., and Beech, I. B. (2000). The effect of extracellular polymeric substances on the attachment of Pseudomonas NCIMB 2021 to AISI 304 and 316 stainless steel. Biofouling 15, 25-36. doi: 10.1080/08927010009386295

Han, J., Kong, C., Heo, J., Yoon, Y., Lee, H., and Her, N. (2012). Removal of perchlorate using reverse osmosis and nanofiltration membranes. Environ. Eng. Res. 17, 185-190. doi: 10.4491/eer.2012.17.4.185

Hess, S. C., Kohll, A. X., Raso, R. A., and Schumacher, C. M. (2015). Template particle stabilized bicontinous emulsion yielding controlled assembly of hierarchical high flux filtration membrane. ACS Appl. Mater. Interf. 7, 611-617. doi: $10.1021 / \mathrm{am} 506737 \mathrm{n}$
Iervolino, M., Mancini, B., and Cristino, S. (2017). Industrial cooling tower disinfection treatment to prevent Legionella spp. Int. J. Environ. Res. Public Health 14:1125. doi: 10.3390/ijerph14101125

Jarraud, S., Descours, G., Ginevra, C., and Lina, G. (2012). Identification of Legionella in clinical samples. Methods Mol. Biol. 954, 27-56. doi: 10.1007/9781-62703-161-5_2

Kaiser, W. J., Stark, N., and Grass, R. (2017). Rapid production of porous cellulose acetate membrane for water filtration using readily available chemicals. J. Chem. Educ. 94, 483-487. doi: 10.1021/acs.jchemed.6b00776

Kenny, J. F., Barber, N. L., Hutson, S. S., Linsey, K. S., Lovelace, J. K., and Maupin, M. A. (2009). Estimated Use of Water in the United States in 2005. Available online at: https://pubs.usgs.gov/circ/1344/pdf/c1344.pdf

Koeman-Stein, N. E., Creusen, R. J. M., Zijlstra, M., Groot, C. K., and van den Broek, W. B. P. (2016). Membrane distillation of industrial cooling tower blowdown water. Water Resour. Indust. 14, 11-17. doi: 10.1016/j.wri.2016. 03.002

Krumholz, L. R., Wang, L., Beck, D. A. C., and Wang, T. (2013). Membrane protein complex of APS reductase and Qmo is present in Desulfovibrio vulgaris and Desulfovibrio alaskensis. Microbiology 159, 2162-2168. doi: 10.1099/mic.0. 063818-0

Latzer, K. (2012). TechTalk. Available online at: http://www.chemtechwater.ca/ attachments/Chemtech\%20Side strea m\%20Techtalk.pdf

Le, N. L., and Nunes, S. P. (2016). Materials and membrane technologies for water and energy sustainability. Sustain. Mater. Technol. 7, 1-28. doi: 10.1016/j. susmat.2016.02.001

Llewellyn, A. C., Lucas, C. E., Roberts, S. E., Brown, E. W., Nayak, B. S., and Raphael, B. H. (2017). Distribution of Legionella and bacterial community composition among regionally diverse US cooling towers. PLoS One 12:e0189937. doi: 10.1371/journal.pone.0189937

Morais, P. A., Rangel, A. O. S. S., and Souto, M. R. S. (2001). Determination of sulfate in natural and residual waters by turbidimetric flow-injection analysis. J. AOAC Int. 84, 59-64. doi: 10.1093/jaoac/84.1.59

Mouchtouri, V., Velonakis, E., Tsakalof, A., and Kapoula, C. (2007). Risk factors for contamination of hotel water distribution systems by Legionella species. Appl. Environ. Microbiol. 73, 1489-1492. doi: 10.1128/aem.021 91-06

Mouchtouri, V. A., Goutziana, G., Kremastinou, J., and Hadjichristodoulou, C. (2010). Legionella species colonization in cooling towers: risk factors and assessment of control measures. Am. J. Infect. Control 38, 50-55. doi: 10.1016/ j.ajic.2009.04.285

Paranjape, K., Bedard, E., Whyte, L. G., and Ronholm, J. (2019). Presence of Legionella spp. in cooling towers: the role of microbial diversity, Pseudomonas, and continuous chlorine application. bioRxiv [Preprint]. doi: 10.1101/ 540302

Parr, E., Whitney, A., and Berkelman, R. L. (2015). Legionellosis on the rise: a review of guidelines for prevention in the United States. J. Public Health Manag. Pract. 21, E17-E26.

Parthuisot, N., West, N. J., Lebaron, P., and Baudart, J. (2010). High diversity and abundance of Legionella spp. in a pristine river and impact of seasonal and anthropogenic effects. Appl. Environ. Microbiol. 76, 8201-8210. doi: 10.1128/ aem.00188-10

Samimi, A. (2013). Micro-organisms of cooling tower problems and how to manage them. Int. J. Basic Appl. Sci. 1, 705-715.

Shannon, M. A., Bohn, P. W., Elimelech, M., and Georgiadis, J. G. (2008). Science and Technology for water purification in the coming decades. Nature 45, 2301-2310.

Sharma, C., Sharma, A. K., Mullick, S. C., and Kandpal, T. C. (2015). Assessment of solar thermal power generation potential in India. Renewable and Sustainable Energy Reviews 42, 902-912. doi: 10.1016/j.rser.2014.10.059

Sharma, N., Lavania, M., Kukreti, V., and Rana, D. P. (2018). Laboratory investigation of indigenous consortia TERIJ-188 for incremental oil recovery. Front. Microbiol. 8:2357. doi: 10.3389/fmicb.2018.2357

Sharma, N., Lavania, M., and Lal, B. (2019). Distribution of pathogenic Legionella species in the cooling towers: a possible cause of Legionnaire's disease. Biomed. J. Sci. Tech. Res. 21, 15820-15823.

Sharmin, F., Wakelin, S., Huygens, F., and Hargreaves, M. (2013). Firmicutes dominate the bacterial taxa within sugar-cane processing plants. Sci. Rep. 3:3107. 
Shukla, M., and Arya, S. (2018). Determination of chloride ion (Cl-1) concentration in Ganga river water by mohr method at Kanpur, India. Green Chem. Tech. Lett. 4, 06-08. doi: 10.18510/gctl.2018.412

Subbaram, K., Kannan, H., and Masadeh, M. M. A. (2017). Isolation, identification, characterization and antibiotic sensitivity profile of pathogenic Legionella pneumophila isolates from different water sources Asian Pac. Asian Pac. J. Trop. Biomed. 7, 411-415. doi: 10.1016/j.apjtb.2016. 12.023

Thomas, V., McDonnell, G., Denyer, S. P., and Maillard, J. Y. (2010). Free-living amoebae and their intracellular pathogenic microorganisms: risks for water quality. FEMS Microbiol. Rev. 34, 231-259. doi: 10.1111/j.1574-6976.2009. 00190.x

Walser, S. M., Gerstner, D. G., Brenner, B., Holler, C., Liebl, B., and Herr, C. E. W. (2014). Assessing the environmental health relevance of cooling towers-a systematic review of legionellosis outbreaks. Int. J. Hyg. Environ. Health 217, 145-154. doi: 10.1016/j.ijheh.2013.08.002

Wery, N., Bru-Adan, V., Minervini, C., Delgenes, J. P., Garrelly, L., and Godon, J. J. (2008). Dynamics of Legionella spp. and bacterial populations during the proliferation of L. pneumophila in a cooling tower facility. Appl. Environ. Microbiol. 74, 3030-3037. doi: 10.1128/aem.02760-07

Yurudu, N. O. S. (2013). "A short methodology review: for the evaluation of biocides against biofilms in recirculating water systems," in Microbial Pathogens and Strategies for Combating them: Science, Technology and Education, ed. A. Méndez-Vilas (Badajoz: Formatex Research Center), $1-10$.

Conflict of Interest: The authors declare that the research was conducted in the absence of any commercial or financial relationships that could be construed as a potential conflict of interest.

Copyright (C) 2020 Sharma, Lavania and Lal. This is an open-access article distributed under the terms of the Creative Commons Attribution License (CC BY). The use, distribution or reproduction in other forums is permitted, provided the original author(s) and the copyright owner(s) are credited and that the original publication in this journal is cited, in accordance with accepted academic practice. No use, distribution or reproduction is permitted which does not comply with these terms. 